\title{
Electrochemical Engineering in the Core of the Dye-Sensitized Solar Cells (DSSCs)
}

\author{
Djamel Ghernaout ${ }^{1,2 *}$, Attia Boudjemline ${ }^{3}$, Noureddine Elboughdiri ${ }^{1,4}$ \\ ${ }^{1}$ Chemical Engineering Department, College of Engineering, University of Ha'il, Ha'il, Saudi Arabia \\ ${ }^{2}$ Chemical Engineering Department, Faculty of Engineering, University of Blida, Blida, Algeria \\ ${ }^{3}$ Industrial Engineering Department, College of Engineering, University of Ha'il, Ha'il, Saudi Arabia \\ ${ }^{4}$ Département de Génie Chimique de Procédés, Laboratoire Modélisation, Analyse, et Commande des systèmes, Ecole Nationale \\ d'Ingénieurs de Gabès (ENIG), Rue Omar Ibn-Elkhattab, Gabès, Tunisia \\ Email: *djamel_andalus@hotmail.com
}

How to cite this paper: Ghernaout, D., Boudjemline, A. and Elboughdiri, N. (2020) Electrochemical Engineering in the Core of the Dye-Sensitized Solar Cells (DSSCs). Open Access Library Journal, 7: e6178. https://doi.org/10.4236/oalib.1106178

Received: February 19, 2020

Accepted: March 20, 2020

Published: March 23, 2020

Copyright $\odot 2020$ by author(s) and Open Access Library Inc.

This work is licensed under the Creative Commons Attribution International License (CC BY 4.0).

http://creativecommons.org/licenses/by/4.0/

\section{(c) (i) Open Access}

\begin{abstract}
Dye-sensitized solar cells (DSSCs) are classed in the category of thin-film solar cells, which have been under thorough investigation during the last thirty years thanks to their low price, easy fabrication procedure, low toxicity and ease of generation. Even now, there are great efforts to substitute the present DSSC materials because of their elevated price, less abundance, and long-term stability. The performance of present DSSCs attains $12 \%$, employing $\mathrm{Ru}(\mathrm{II})$ dyes via regulating material and structural features, which remains less than the performance given by first- and second-generation solar cells, i.e., other thin-film solar cells and Si-based solar cells which provide $20 \%$ $30 \%$ performance. This work focuses on the main findings of Sharma et al. [1] which presented an in-depth review on DSSC fabrication, running principle, fundamental issues (low efficiency, low scalability, and low stability), prospective efficient materials, and finally a brief insight to commercialization.
\end{abstract}

\section{Subject Areas \\ Electric Engineering}

\section{Keywords}

Dye-Sensitized Solar Cells (DSSCs), Photoanode, Counter Electrode (CE), Electrolytes, Metal and Metal-Free Organic Dyes, Efficiency, Stability

\section{Introduction}

As a technically and economically possible option to the p-n junction photovol- 
taic systems, dye-sensitized solar cells (DSSCs) have emerged [1]. In the late 1960 s, it was found that electricity can be produced via illuminated organic dyes in electrochemical cells. At the University of California at Berkeley, chlorophyll was extracted from spinach (photosynthesis). In 1972, earliest chlorophyll-sensitized zinc oxide $(\mathrm{ZnO})$ electrode was synthesized. For the first time, via electron injection of excited dye molecules into a large band gap of semiconductor, photons were transformed into electricity [1]. Great investigations have been realized on $\mathrm{ZnO}$-single crystals [2]; however, the performance of such dye-sensitized solar cells was too low, since the monolayer of dye molecules was capable to absorb incident light only up to $1 \%$. Therefore, the performance was ameliorated via regulating the porosity of the electrode constituted of fine oxide powder; as a result, the absorption of dye over electrode can be improved and then light harvesting efficiency (LHE) can as well be ameliorated. Thus, nano-porous titanium dioxide $\left(\mathrm{TiO}_{2}\right)$ electrodes with a roughness factor of ca.1000 were presented; and in 1991, DSSCs with 7\% performance were presented [3]. Such cells, as well famous as Grätzel cells, were firstly co-invented in 1988 by Brian O'Regan and Michael Grätzel at UC Berkeley [3] and were more improved by the aforesaid researchers at École Polytechnique Fédèrale de Lausanne (ÉPFL) until 1991.

O’Regan and Grätzel manufactured an apparatus founded on a $10-\mu \mathrm{m}$-thick, elevated surface area and optically transparent film of $\mathrm{TiO}_{2}$ nanoparticles, coated with a monolayer of a charge transfer dye with ideal spectral properties to sensitize the film for light harvesting. The system collected an elevated portion of the incident solar energy flux of $46 \%$ and offered unusually elevated performances, even more than $80 \%$ performances for the transformation of incident photons to electrical current. The overall incident photon to current conversion efficiency (IPCE) yield was 7.1\% - 7.9\% in simulated solar light and $12 \%$ in diffuse daylight. A big short circuit current density $J_{\text {SC }}$ (greater than $12 \mathrm{~mA} / \mathrm{cm}^{2}$ ) and exceptional stability (sustaining at least five million turnovers without decomposition) and low cost rendered the practical utilization possible [3]. In 1993, Grätzel and his colleagues mentioned 9.6\% performance of cells; and four years later, they attained $10 \%$ at the National Renewable Energy Laboratory (NREL). The sensitizers are commonly designed to possess functional groups like - $\mathrm{COOH},-\mathrm{PO}_{3} \mathrm{H}_{2}$, and $-\mathrm{B}(\mathrm{OH})_{2}$ for stable adsorption onto the semiconductor substrate [4] [5]. Two years ago 2018, a performance of $8.75 \%$ was noted for hybrid dye-titania nanoparticle-based DSSC for superior low temperature [6]. In a conventional solar cell, Si gives two roles: works as source of photoelectrons and furnishes electric field to separate the charges and generate a current. However, in DSSCs, the bulk of semiconductor is exclusively employed as a charge transporter and the photoelectrons are furnished by photosensitive dyes. The theoretically anticipated power conversion efficiency (PCE) of DSSCs was around 20\% [7] [8]; therefore, considerable investigations have been dedicated during the least years on DSSCs to increase their performance. 
The ameliorations and augmenting dares in dye-sensitized solar cells until 2007 were discussed [9]. The major elements of this discussion were light harvesting inorganic dye molecules, $\mathrm{p}-\mathrm{CuO}$ nanorod counter electrodes (CEs), and self-organization of electroactive polymers; further, this work explained how such materials perform in a rationally designed solar cell. Nevertheless, the maximum IPCE of 7\% was debated in the review paper for naphthyridine coordinated $\mathrm{Ru}$ complex [10] which was good till 2007 but is almost half to the efficiencies shown in later work. Bose et al. [11] focused on the current state and enhancements in the domain of photoelectrode, photosensitizer, and electrolyte for DSSCs up to 2015. They juxtaposed the efficiency of the DSSC module with that of the Si-founded module by the graph illustrated in Figure 1 [12], and concluded that the efficiency of the DSSC module is far better than that of the Si module. Plus, the most important performance debated in this review paper was $11.2 \%$ for N719 dye-based DSSC.

Researchers [13] concentrated on sensitizers, comprising on ruthenium complexes, metal-free organic dyes, quantum-dot sensitizer, perovskite-based sensitizer, mordant dyes, and natural dyes. Further, they furnished a deep discussion about the various sorts of sensitizers; however, there is no details concerning additional crucial components of the DSSCs. In addition, apart from debating all diverse components of DSSCs, scientists [14] focused on the CE side. They analyzed the investigation of various kinds of CEs founded on transparency and flexibility, metals and alloys, carbon materials, conductive polymers, transition metal compounds, and hybrids. A most elevated performance of $14.3 \%$ was examined for the DSSC fabricated with $\mathrm{Au} / \mathrm{GNP}$ as a $\mathrm{CE}, \mathrm{Co}^{3+/ 2+}$ as a redox couple, and LEG4 + ADEKA-1 as a sensitizer [15] and was shown in the review article. Similarly, researchers [16] [17] evaluated the photoanode of DSSC. They have categorized alteration of photoanode into three classes: interfacial change via the introduction of blocking and scattering layer, compositing, doping with non-metallic anions and metallic cations, interfacial engineering, and replacing the conventional mesoporous semiconducting metal oxide films like with 1-D or 2-D nanostructures.

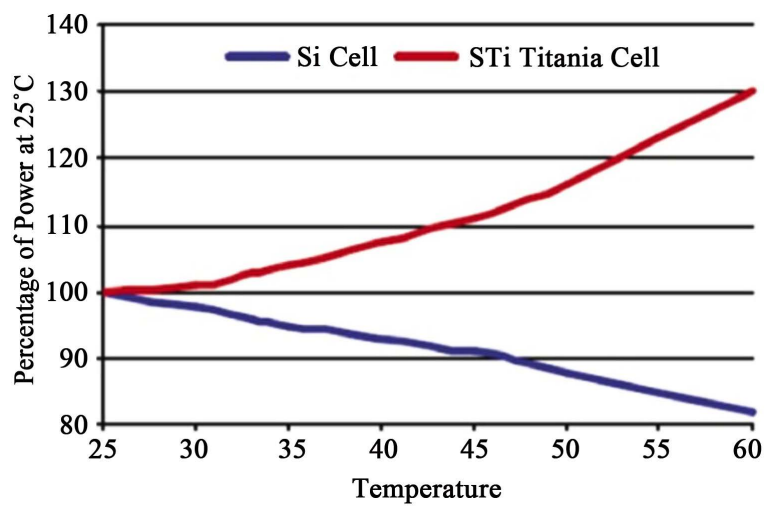

Figure 1. The performance of dye PV modules increases with temperature, contrary to Si-based modules [11] [12]. 
Consequently, via juxtaposing various reviews, it may be readily shown that the review paper published by Sharma et al. [1] presented the insight investigation of diverse components and their utilization in DSSCs as well as fabrication and working of these cells.

\section{Fabrication and Working of DSSCs}

The working electrode (WE), sensitizer (dye), redox-mediator (electrolyte), and CE are four fundamental factors for a DSSC. DSSC is an assembly of WE soaked with a sensitizer or a dye and sealed to the CE soaked with a thin layer of electrolyte with the help of a hot melt tape to prevent the leakage of the electrolyte (as illustrated in Figure 2). The components as well as the construction and working of DSSCs are explained below [1].

\subsection{Transparent and Conductive Substrate}

DSSCs are usually fabricated with two sheets of conductive transparent materials, which assist a substrate for the deposition of the semiconductor and catalyst, working as well like current collectors [18] [19]. There are two principal properties of a substrate being employed in a DSSC: 1) more than $80 \%$ of transparency is needed by the substrate to let the passage of optimum sunlight to the efficient area of the cell; 2) for the performant charge transfer and decreased energy loss in DSSCs, it has to possess an elevated electrical conductivity. The fluorine-doped tin oxide (FTO, $\mathrm{SnO}_{2}: \mathrm{F}$ ) and indium-doped tin oxide (ITO, $\mathrm{In}_{2} \mathrm{O}_{3}: \mathrm{Sn}$ ) are commonly implemented as a conductive substrate in DSSCs. Such substrates are composed of soda lime glass coated with the layers of indium-doped tin oxide and fluorine-doped tin oxide. The ITO films possess a transmittance $>$ $80 \%$ and $18 \Omega / \mathrm{cm}^{2}$ of sheet resistance; however, FTO films depict a lower transmittance of $\sim 75 \%$ in the visible region and sheet resistance of $8.5 \Omega / \mathrm{cm}^{2}[18]$.

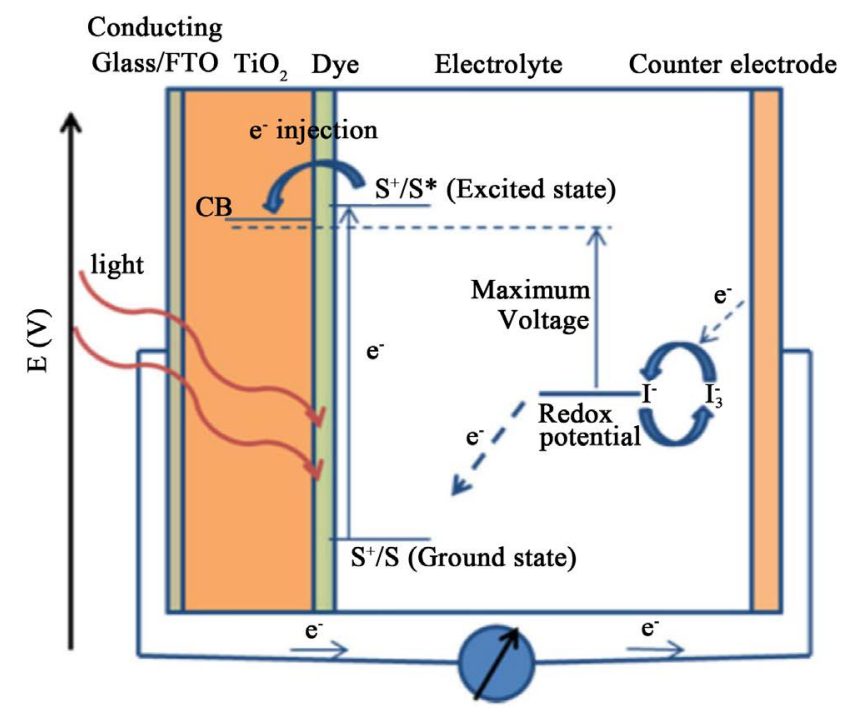

Figure 2. Construction and working principle of the dye-sensitized nanocrystalline solar cells [1]. 


\subsection{Working Electrode (WE)}

The WEs are made via depositing a thin layer of oxide semiconducting materials like $\mathrm{TiO}_{2}, \mathrm{Nb}_{2} \mathrm{O}_{5}, \mathrm{ZnO}, \mathrm{SnO}_{2}$ (n-type), and $\mathrm{NiO}$ (p-type) on a transparent conducting glass plate made of FTO or ITO. Such oxides possess a large energy band gap of $3-3.2 \mathrm{eV}$. Implementing an anatase allotropic form of $\mathrm{TiO}_{2}$ is more commendable in DSSCs as juxtaposed with a rutile form thanks to its higher energy band gap of $3.2 \mathrm{eV}$ whereas the rutile form has a band gap of about $3 \mathrm{eV}$ [20] [21], even if alternative large band gap oxides like $\mathrm{ZnO}$ and $\mathrm{Nb}_{2} \mathrm{O}_{5}$ possess as well given encouraging findings [22] [23]. Thanks to being non-toxic and less expensive and its easy availability, $\mathrm{TiO}_{2}$ is mostly utilized as a semiconducting layer. Nevertheless, such semiconducting layers absorb only a small portion of light in the UV region; consequently, such WEs are then immersed in a mixture of a photosensitive molecular sensitizer and a solvent. After soaking the film within the dye solution, the dye gets covalently bonded to the $\mathrm{TiO}_{2}$ surface. Because of the highly porous structure and the huge surface area of the electrode, a high number of dye molecules get fixed on the nanocrystalline $\mathrm{TiO}_{2}$ surface, and therefore, light absorption at the semiconductor surface augments [1].

\subsection{Photosensitizer or Dye}

Dye is the component of DSSC in charge of the maximum absorption of the incident light. Any material being dye has to possess numerous photophysical and electrochemical properties. Some of them are listed in Table 1 [1].

Table 1. Dye photophysical and electrochemical properties [1].

\begin{tabular}{|c|c|}
\hline Property & Description \\
\hline Property \#1 & The dye has to be luminescent. \\
\hline Property\#2 & $\begin{array}{l}\text { The absorption spectra of the dye has to include ultraviolet-visible } \\
\text { (UV-vis) and near-infrared region (NIR) regions. }\end{array}$ \\
\hline & $\begin{array}{l}\text { The highest occupied molecular orbital }(\mathrm{HOMO}) \text { has to be found far } \\
\text { from the surface of the conduction band of } \mathrm{TiO}_{2} \text { and the lowest }\end{array}$ \\
\hline Property\#3 & $\begin{array}{l}\text { unoccupied molecular orbital (LUMO) has to be located as near } \\
\text { to the surface of the } \mathrm{TiO}_{2} \text {, and then has to be higher with } \\
\text { respect to the } \mathrm{TiO}_{2} \text { conduction band potential. }\end{array}$ \\
\hline Property \#4 & HOMO should lie lower than that of redox electrolytes. \\
\hline & $\begin{array}{l}\text { The periphery of the dye has to be hydrophobic to improve the } \\
\text { long-term stability of cells, since it conducts to reduced direct }\end{array}$ \\
\hline Property\#5 & $\begin{array}{l}\text { contact among electrolyte and anode; if not, water-induced distortion } \\
\text { of the dye from the } \mathrm{TiO}_{2} \text { surface may take place, which may } \\
\text { diminish the stability of cells. }\end{array}$ \\
\hline Property\#6 & $\begin{array}{l}\text { To avert the accumulation of the dye over the } \mathrm{TiO}_{2} \text { surface, } \\
\text { co-absorbents such as chenodeoxycholic acid (CDCA) and anchoring } \\
\text { groups like alkoxy-silyl [24], phosphoric acid [25], and carboxylic acid } \\
\text { group [26] [27] were integrated among the dye and } \mathrm{TiO}_{2} \text {. This leads } \\
\text { to the prohibition of dye gathering and therefore restricts the } \\
\text { recombination reaction [28] among redox electrolyte and electrons in the } \\
\mathrm{TiO}_{2} \text { nanolayer as well as conducts to the generation of stable linkage. }\end{array}$ \\
\hline
\end{tabular}




\subsection{Electrolyte}

An electrolyte (like $\mathrm{I}^{-} / \mathrm{I}_{3}^{-}, \mathrm{Br}^{-} / \mathrm{Br}_{2}^{-}$[29], $\mathrm{SCN}^{-} / \mathrm{SCN}_{2}$ [30], and $\mathrm{Co}(\mathrm{II}) / \mathrm{Co}$ (III) [31]) possesses five major components, i.e., redox couple, solvent, additives, ionic liquids (ILs), and cations. An electrolyte has to possess the mentioned features in Table 2 [1].

Further, $\mathrm{I}^{-} / \mathrm{I}_{3}^{-}$has been established as a highly efficacious electrolyte [32]; however, there are some restrictions related to its usage in DSSCs [1]. In fact, $\mathrm{I}^{-} / \mathrm{I}_{3}^{-}$electrolyte corrodes glass $/ \mathrm{TiO}_{2} / \mathrm{Pt}$; it is greatly volatile and responsible for photodegradation and dye desorption and possesses poor long-term stability [33] [34]. Acetonitrile (ACN), $N$-methylpyrrolidine (NMP), and solvent mixtures, like ACN/valeronitrile, have been utilized as a solvent as possessing elevated dielectric constants. 4-Tert-butylpyridine (TBP) is mainly employed as an additive to shift the conduction band of $\mathrm{TiO}_{2}$ upwards, which conducts to an augmentation of the value of open circuit voltage $\left(V_{\mathrm{OC}}\right)$, decreased cell photocurrent $\left(J_{\mathrm{sC}}\right)$, and less injection driving force. It is suggested that TBP on a $\mathrm{TiO}_{2}$ surface diminishes recombination via back transfer to an electrolyte [35]. Nevertheless, the biggest disadvantage related to the IL is their leakage factor. Consequently, solid-state electrolytes are expanded to avert the disadvantages linked with IL electrolytes [36]. Further, to examine the failure of the redox electrolyte or the sealing under long-term illumination, long-term light soaking experiments on sealed cells have also progressed greatly during the decades [37].

\subsection{Counter Electrode (CE)}

In DSSCs, CEs are usually synthetized via employing platinum (Pt) or carbon (C). Both functioning and CEs are sealed jointly, and subsequently, an electrolyte is filled with a help of a syringe. CE catalyzes the reduction of $\mathrm{I}^{-} / \mathrm{I}_{3}^{-}$liquid electrolyte and collects holes from the hole transport materials (HTMs). Pt is employed frequently as a CE since it depicts more important performances [38]; however, substituting Pt was much requested thanks to its higher cost and less abundance [1]. Then, numerous trials have realized to substitute Pt in DSSCs, like carbon [39], carbonylsulfide (CoS) [40], Au/GNP [15], alloy CEs like FeSe [41], and $\mathrm{CoNi}_{0.25}$ [42], even if the various kinds of the CEs are also reviewed by Jihuai Wu et al. [14].

Table 2. Electrolyte main features [1].

\begin{tabular}{|c|c|}
\hline Feature & Description \\
\hline Feature \# 1 & Redox couple has to be capable to regenerate the oxidized dye efficaciously. \\
\hline Feature \#2 & Has to possess long-term chemical, thermal, and electrochemical stability. \\
\hline Feature \#3 & Should be non-corrosive with DSSC components. \\
\hline Feature \#4 & $\begin{array}{l}\text { Has to be apt to let quick transfer of charge carriers, improve conductivity, } \\
\text { and generate efficacious contact among the working and CEs. }\end{array}$ \\
\hline Feature \#5 & $\begin{array}{l}\text { Absorption spectra of an electrolyte have not to overlap with the } \\
\text { absorption spectra of a dye. }\end{array}$ \\
\hline
\end{tabular}




\section{Working Principle}

The working principle of DSSC implies four fundamental stages: light absorption, electron injection, transportation of carrier, and collection of current. Table 3 lists the main stages implicated in transforming photons into current (as illustrated in Figure 2) [1].

\section{Former and Additional Refinements in DSSCs}

To enhance and investigate the efficiency of DSSCs, diverse electrolytes such as gel electrolytes, quasi-solid-state electrolytes, IL electrolytes, etc., have been utilized as mediators so far [1]. Nevertheless, a changing tendency to regulate the efficiency of the DSSCs has been introduced via adding the energy relay dyes to the electrolyte.

The cells performance via liquid electrolyte may be elevated through introducing iodide/triiodide redox couple and high dielectric constant organic solvents such as $\mathrm{ACN}$, 3-methoxypropionitrile (MePN), propylene carbonate (PC), $\gamma$-butyrolactone (GBL), $N$-methyl-2-pyrrolidone (NMP), ethylene carbonate (EC), and counter ions of iodides, where solvents are the basic component of a liquid electrolyte. Following their stability, organic solvents can be sequenced as imidazolium < picolinium < alkylpyridinium. Between numerous features of solvents such as donor number, dielectric constants, and viscosity, the donor

Table 3. Main stages implicated in transforming photons into current [1].

\begin{tabular}{|c|c|}
\hline Stage & Description \\
\hline Stage \# 1 & $\begin{array}{l}\text { The incident light (photon) is absorbed via a photosensitizer, and therefore, } \\
\text { due to the photon absorption, electrons get promoted from the ground } \\
\text { state }\left(\mathrm{S}^{+} / \mathrm{S}\right) \text { to the excited state }\left(\mathrm{S}^{+} / \mathrm{S}^{*}\right) \text { of the dye, where the absorption } \\
\text { for most of the dye is in the domain of } 700 \mathrm{~nm} \text { which corresponds to the } \\
\text { photon energy almost about } 1.72 \mathrm{eV} \text {. }\end{array}$ \\
\hline Stage\#2 & $\begin{array}{l}\text { The excited electrons with a lifetime of nanosecond span are injected into the } \\
\text { conduction band of nanoporous } \mathrm{TiO}_{2} \text { electrode which lies below the excited } \\
\text { state of the dye, where the } \mathrm{TiO}_{2} \text { absorbs a small fraction of the solar } \\
\text { photons from the UV region [43]. Consequently, the dye gets oxidized. } \\
\mathrm{S}^{+} / \mathrm{S}+\mathrm{h} v \rightarrow \mathrm{S}^{+} / \mathrm{S}^{*} \\
\mathrm{~S}^{+} / \mathrm{S}^{*} \rightarrow \mathrm{S}^{+} / \mathrm{S}+\mathrm{e}^{-}\left(\mathrm{TiO}_{2}\right)\end{array}$ \\
\hline Stage\#3 & $\begin{array}{l}\text { Such injected electrons are transported among } \mathrm{TiO}_{2} \text { nanoparticles and } \\
\text { diffuse towards the back contact (transparent conducting oxide [TCO]). } \\
\text { Via the external circuit, electrons attain the CE. }\end{array}$ \\
\hline Stage\#4 & $\begin{array}{l}\text { The electrons at the CE reduce } \mathrm{I}_{3}^{-} \text {to } \mathrm{I}^{-} \text {; therefore, dye regeneration } \\
\text { or the regeneration of the ground state of the dye occurs thanks to the } \\
\text { acceptance of electrons from } \mathrm{I}^{-} \text {ion redox mediator, and } \mathrm{I}^{-} \text {gets } \\
\text { oxidized to } \mathrm{I}_{3}^{-} \text {(oxidized state). } \\
\mathrm{S}^{+} / \mathrm{S}^{*}+\mathrm{e}^{-} \rightarrow \mathrm{S}^{+} / \mathrm{S}\end{array}$ \\
\hline Stage\#5 & $\begin{array}{l}\text { Plus, the oxidized mediator ( } \mathrm{I}_{3}^{-} \text {) diffuses towards the } \mathrm{CE} \text { and reduces to } \mathrm{I} \text { ion. } \\
\mathrm{I}_{3}^{-}+2 \mathrm{e}^{-} \rightarrow 3 \mathrm{I}^{-}\end{array}$ \\
\hline
\end{tabular}


number depicts obvious impact on the $V_{\mathrm{OC}}$ and $J_{\mathrm{SC}}$ of DSSCs. Injecting the small quantity of electric additives such as $N$-methylbenzimidazole (NMBI), guanidinium thiocyanate (GuSCN), and TBP greatly ameliorates the cell efficiency. Just like solvents, a co-absorbent as well possesses a fundamental contribution in the running and efficiency of an electrolyte. Introducing co-absorbents in an electrolyte trims down the charge recombination of photoelectrons in the semiconductor with the redox shuttle of the electrolyte. Secondly, a co-absorbent may modify the band edge position of the $\mathrm{TiO}_{2}$-conduction band, therefore leading to an elevation in the value of $V_{\mathrm{OC}}$ of the cell. This avoids the dye gathering over the $\mathrm{TiO}_{2}$ surface and conducts to long-term stability of the cell as well as augmentation in $V_{\mathrm{OC}}$.

\section{Conclusions}

From this work, the following conclusions can be drawn:

1) The principal objective of this work was to present a summary of the pertinent discussion presented by Sharma et al. [1] on fresh materials for photoanodes, CEs, electrolytes, and sensitizers as to present low-cost, flexible, environmentally sustainable, and easy ways to fabricate DSSCs. Nevertheless, a brief explanation has been provided to greater comprehend the running components of DSSCs [11]. Further, this work focused on a link among the photosensitizer composition, the interfacial charge transfer reactions, and the setup efficiency which are crucial to understand as to expand novel metal and metal-free organic dyes. In matter of low stability given by DSSCs, two main difficulties, i.e., low intrinsic stability and the sealing of the electrolytes (extrinsic stability), have been undertaken in this discussion. To fulfill great request of electricity and power, there are two best possible solutions: this demand has to be compensated either by the nuclear fission or by the sun. Even so, the nuclear fission predicted to be the best alternative has considerable ecological problems as well as issues related to its waste disposal. As a result, the second option remains better to consider. DSSCs are developed as a cheap alternative; however, the performance given by DSSCs in the domain stays not enough. Therefore, a large study on all likely features of DSSCs has to be explored. Sharma et al. [1] suggested to develop DSCCs founded on diverse electrodes viz. graphene, nanowires, nanotubes, and quantum dots; novel photosensitizers founded on metal complexes of $\mathrm{Ru}$ or Os/organic metal-free complexes/natural dyes; and fresh electrolytes founded on imidazolium salts/pyridinium salts/conjugated polymers, gel electrolytes, polymer electrolytes, and water-based electrolytes. So far, large researches have been performed treating individual dares related to working electrode, dye, and electrolytes separately; therefore, a global manner requires to be employed where all these difficulties have to be handled jointly via selecting suitable circumstances of electrolyte (both in choice of material and structure), optimum dye, and the most stable electrolyte which gives better electron transportation capability [1]. 


\section{Conflicts of Interest}

The authors declare no conflicts of interest regarding the publication of this paper.

\section{References}

[1] Sharma, K., Sharma, V. and Sharma, S.S. (2018) Dye-Sensitized Solar Cells: Fundamentals and Current Status. Nanoscale Research Letters, 13, 381. https://doi.org/10.1186/s11671-018-2760-6

[2] Tsubomura, H., Matsumura, M., Nomura, Y. and Amamiya, T. (1976) Dye Sensitised Zinc Oxide: Aqueous Electrolyte: Platinum Photocell. Nature, 261, 402-403. https://doi.org/10.1038/261402a0

[3] O’Regan, B. and Grätzel, M. (1991) A Low-Cost, High-Efficiency Solar Cell Based on Dye-Sensitized Colloidal $\mathrm{TiO}_{2}$ Films. Nature, 353, 737-740. https://doi.org/10.1038/353737a0

[4] Nazeeruddin, K., Baranoff, E. and Grätzel, M. (2011) Dye-Sensitized Solar Cells: A Brief Overview. Solar Energy, 85, 1172-1178. https://doi.org/10.1016/j.solener.2011.01.018

[5] Altobello, S., Bignozzi, C., Caramori, S., Larramona, G., Quici, S., Marzanni, G. and Lakhmiri, R. (2004) Sensitization of $\mathrm{TiO}_{2}$ with Ruthenium Complexes Containing Boronic Acid Functions. Journal of Photochemistry and Photobiology A: Chemistry, 166, 91-98. https://doi.org/10.1016/j.jphotochem.2004.04.029

[6] Kunzmann, A., Valero, S.E., Sepúlveda, A., Rico-Santacruz, M., Lalinde, E.R., Berenguer, J., García-Martínez, J.M., Guldi, D., Serrano, E.D. and Costa, R. (2018) Hybrid Dye-Titania Nanoparticles for Superior Low-Temperature Dye-Sensitized Solar Cells. Advanced Energy Materials, 8, 121-212. https://doi.org/10.1002/aenm.201702583

[7] Snaith, H.J. (2010) Estimating the Maximum Attainable Efficiency in Dye-Sensitized Solar Cells. Advanced Functional Materials, 20, 13-19.

https://doi.org/10.1002/adfm.200901476

[8] Frank, A.J., Kopidakis, N. and de Lagemaat, J.V. (2004) Electrons in Nanostructured $\mathrm{TiO}_{2}$ Solar Cells: Transport, Recombination and Photovoltaic Properties. Coordination Chemistry Reviews, 248, 1165-1179. https://doi.org/10.1016/j.ccr.2004.03.015

[9] Anandan, S. (2007) Recent Improvements and Arising Challenges in Dye-Sensitized Solar Cells. Solar Energy Materials and Solar Cells, 91, 843-846. https://doi.org/10.1016/j.solmat.2006.11.017

[10] Anandan, S., Madhavan, J., Maruthamuthu, P., Raghukumar, V. and Ramakrishnan, V.T. (2004) Synthesis and Characterization of Naphthyridine and Acridinedione Ligands Coordinated Ruthenium (II) Complexes and Their Applications in Dye-Sensitized Solar Cells. Solar Energy Materials and Solar Cells, 81, 419-428. https://doi.org/10.1016/j.solmat.2003.11.026

[11] Bose, S., Soni, V. and Genwa, K.R. (2015) Recent Advances and Future Prospects for Dye Sensitized Solar Cells: A Review. International Journal of Scientific and Research Publications, 5, 1-9. https://doi.org/10.1515/irsr-2015-0001

[12] Lee, C., Lin, Y., Lin, L., Li, C., Chu, T., Sun, S., Lin, J.T. and Ho, K. (2015) Recent Progress in Organic Sensitizers for Dye-Sensitized Solar Cells. RSC Advances, 5, 23810-23825. https://doi.org/10.1039/C4RA16493H 
[13] Shalini, S., Balasundaraprabhu, R., Satish Kumar, T., Prabavathy, N., Senthilarasu, S. and Prasanna, S. (2016) Status and Outlook of Sensitizers/Dyes Used in Dye Sensitized Solar Cells (DSSC): A Review: Sensitizers for DSSC. International Journal of Energy Research, 40, 1303-1320. https://doi.org/10.1002/er.3538

[14] Wu, J., Lan, Z., Lin, J., Huang, M., Huang, Y., Fan, L., Luo, G., Lin, Y., Xie, Y. and Wei, Y. (2017) Counter Electrodes in Dye-Sensitized Solar Cells. Chemical Society Reviews, 46, 5975-6023. https://doi.org/10.1039/C6CS00752J

[15] Kakiage, K., Aoyama, Y., Yano, T., Oya, K., Fujisawab, J. and Hanaya, M. (2015) Highly-Efficient Dye-Sensitized Solar Cells with Collaborative Sensitization by Silyl-Anchor and Carboxy-Anchor Dyes. Chemical Communications, 51, 15894-15897. https://doi.org/10.1039/C5CC06759F

[16] Yeoh, M.E. and Chan, K.Y. (2017) Recent Advances in Photo-Anode for Dye-Sensitized Solar Cells: A Review. International Journal of Energy Research, 41, 2446-2467. https://doi.org/10.1002/er.3764

[17] Fan, K., Yu, J. and Ho, W. (2017) Improving Photoanodes to Obtain Highly Efficient Dye-Sensitized Solar Cells: A Brief Review. Materials Horizons, 4, 319-344. https://doi.org/10.1039/C6MH00511I

[18] Richhariya, G., Kumar, A., Tekasakul, P. and Gupta, B. (2017) Natural Dyes for Dye Sensitized Solar Cell: A Review. Renewable and Sustainable Energy Reviews, 69, 705-718. https://doi.org/10.1016/j.rser.2016.11.198

[19] Andualem, A. and Demiss, S. (2018) Review on Dye-Sensitized Solar Cells (DSSCs). Edelweiss Applied Science and Technology, 2, 145-150. https://doi.org/10.33805/2576-8484.130

[20] Grant, F.A. (1959) Properties of Rutile (Titanium Dioxide). Reviews of Modern Physics, 31, 646-674. https://doi.org/10.1103/RevModPhys.31.646

[21] Maddah, H.A., Berry, V. and Behura, S.K. (2020) Biomolecular Photosensitizers for Dye-Sensitized Solar Cells: Recent Developments and Critical Insights. Renewable and Sustainable Energy Reviews, 121, Article ID: 109678. https://doi.org/10.1016/j.rser.2019.109678

[22] Tennakone, K., Kumara, G.R.R.A., Kottegoda, I.R.M. and Vps, P. (1999) An Efficient Dye-Sensitized Photoelectrochemical Solar Cell Made from Oxides of Tin and Zinc. Chemical Communications, 1, 15-16. https://doi.org/10.1039/a806801a

[23] Sayama, K., Sugihara, H. and Arakawa, H. (1998) Photoelectrochemical Properties of a Porous $\mathrm{Nb}_{2} \mathrm{O}_{5}$ Electrode Sensitized by a Ruthenium Dye. Chemistry of Materials, 10, 3825-3832. https://doi.org/10.1021/cm9801111

[24] Fung, A.K.M., Chiu, B. and Lam, M.H.W. (2003) Surface Modification of $\mathrm{TiO}_{2}$ by a Ruthenium(II) Polypyridyl Complex via Silyl-Linkage for the Sensitized Photocatalytic Degradation of Carbon Tetrachloride by Visible Irradiation. Water Research, 37, 1939-1947. https://doi.org/10.1016/S0043-1354(02)00567-5

[25] Zaban, A., Ferrere, S. and Gregg, B.A. (1998) Relative Energetics at the Semiconductor/Sensitizing Dye/Electrolyte Interface. The Journal of Physical Chemistry, 102, 452-460. https://doi.org/10.1021/jp972924n

[26] Nazeeruddin, M.K., Kay, A., Rodicio, I., Humphry-Baker, R., Mueller, E., Liska, P., Vlachopoulos, N. and Graetzel, M. (1993) Conversion of Light to Electricity by Cis-X2bis(2,2'-bipyridyl-4,4'-dicarboxylate)ruthenium(II) Charge-Transfer Sensitizers (X = Cl-, Br-, I-, CN-, and SCN-) on Nanocrystalline Titanium Dioxide Electrodes. Journal of the American Chemical Society, 115, 6382-6390.

https://doi.org/10.1021/ja00067a063 
[27] Hagberg, D.P., Yum, J.H., Lee, H., De Angelis, F., Marinado, T., Karlsson, K.M., Humphry-Baker, R., Sun, L., Hagfeldt, A., Grätzel, M. and Nazeeruddin, M.K. (2008) Molecular Engineering of Organic Sensitizers for Dye-Sensitized Solar Cell Applications. Journal of the American Chemical Society, 130, 6259-6266. https://doi.org/10.1021/ja800066y

[28] Neale, N.R., Kopidakis, N., van de Lagemaat, J., Grätzel, M. and Frank, A.J. (2005) Effect of a Co-Adsorbent on the Performance of Dye-Sensitized $\mathrm{TiO}_{2}$ Solar Cells: Shielding versus Band-Edge Movement. The Journal of Physical Chemistry B, 109, 23183-23189. https://doi.org/10.1021/jp0538666

[29] Ferrere, S., Zaban, A. and Gregg, B.A. (1997) Dye Sensitization of Nanocrystalline Tin Oxide by Perylene Derivatives. The Journal of Physical Chemistry B, 101, 4490-4493. https://doi.org/10.1021/jp970683d

[30] Oskam, G., Bergeron, B.V., Meyer, G.J. and Searson, P.C. (2001) Pseudohalogens for Dye Sensitized $\mathrm{TiO}_{2}$ Photoelectrochemical Cell. The Journal of Physical Chemistry $B, 105,6867-6873$. https://doi.org/10.1021/jp004411d

[31] Nusbaumer, H., Moser, J.E. and Zakeeruddin, S.M. (2001) $\mathrm{Co}^{\mathrm{II}}(\mathrm{dbbip})_{2}{ }^{2+}$ Complex Rivals Tri-Iodide/Iodide Redox Mediator in Dye Sensitized Photovoltaic Cells. The Journal of Physical Chemistry B, 105, 10461-10464. https://doi.org/10.1021/jp012075a

[32] Gao, F., Wang, Y., Shi, D., Zhang, J., Wang, M., Jing, X., Humphry-Baker, R., Wang, P., Zakeeruddin, S.M. and Grätzel, M. (2008) Enhance the Optical Absorptivity of Nanocrystalline $\mathrm{TiO}_{2}$ Film with High Molar Extinction Coefficient Ruthenium Sensitizers for High Performance Dye Sensitized Solar Cells. Journal of the American Chemical Society, 130, 10720-10728. https://doi.org/10.1021/ja801942j

[33] Wu, J., Lan, Z., Hao, S., Li, P., Lin, J. and Huang, M. (2008) Progress on the Electrolytes for Dye-Sensitized Solar Cells. Pure and Applied Chemistry, 80, 2241-2258. https://doi.org/10.1351/pac200880112241

[34] Toivola, M., Ahlskog, F. and Lund, P. (2006) Industrial Sheet Metals for Nanocrystalline Dye-Sensitized Solar Cell Structures. Solar Energy Materials and Solar Cells, 90, 2881-2893. https://doi.org/10.1016/j.solmat.2006.05.002

[35] Kay, H.A. and Grätzel, M. (1996) Low Cost Photovoltaic Modules Based on Dye Sensitized Nanocrystalline Titanium Dioxide and Carbon Powder. Solar Energy Materials and Solar Cells, 44, 99-117. https://doi.org/10.1016/0927-0248(96)00063-3

[36] Wang, M., Anghel, A.M., Marsan, B., Cevey Ha, N.L., Pootrakulchote, N., Zakeeruddin, S.M. and Grätzel, M. (2009) CoS Supersedes Pt as Efficient Electrocatalyst for Triiodide Reduction in Dye-Sensitized Solar Cells. Journal of the American Chemical Society, 131, 15976-15977. https://doi.org/10.1021/ja905970y

[37] Fakharuddin, A., Jose, R., Brown, T.M., Fabregat-Santiago, F. and Bisquert, J. (2014) A Perspective on the Production of Dye-Sensitized Solar Modules. Energy \& Environmental Science, 7, 3952-3981. https://doi.org/10.1039/C4EE01724B

[38] Grätzel, M. and Moser, J.E. (2001) Solar Energy Conversion. In: Balzani, V., Ed., Electron Transfer in Chemistry, Vol. 5, Wiley-VCH, Weiheim, 589-644.

[39] Wang, H.-J., Chen, C.P. and Jeng, R.J. (2014) Polythiophenes Comprising Conjugated Pendants for Polymer Solar Cells: A Review. Materials, 7, 2411-2439. https://doi.org/10.3390/ma7042411

[40] Grätzel, M. (2005) Solar Energy Conversion by Dye-Sensitized Photovoltaic Cells. Inorganic Chemistry, 44, 6841-6851. https://doi.org/10.1021/ic0508371

[41] Cai, H., Tang, Q., He, B., Li, R. and Yu, L. (2014) Bifacial Dye-Sensitized Solar Cells 
with Enhanced Rear Efficiency and Power Output. Nanoscale, 6, 15127-15133. https://doi.org/10.1039/C4NR04911J

[42] Liu, J., Tang, Q., He, B. and Yu, L. (2015) Cost-Effective, Transparent Iron Selenide Nanoporous Alloy Counter Electrode for Bifacial Dye-Sensitized Solar Cell. Journal of Power Sources, 282, 79-86. https://doi.org/10.1016/j.jpowsour.2015.02.045

[43] Kusama, H., Orita, H. and Sugihara, H. (2008) $\mathrm{TiO}_{2}$ Band Shift by Nitrogen-Containing Heterocycles in Dye-Sensitized Solar Cells: A Periodic Density Functional Theory Study. Langmuir, 24, 4411-4419.

https://doi.org/10.1021/la703696f 